UDK 783:281.961(= 83):271(497.13 Krka)

\title{
UKRAINIAN MELODIES IN THE SERBIAN MONASTERY OF KRKA (DALMATIA)
}

\section{Danica Petrović (Beograd)}

In the Library of the Serbian Monastery of Krka in Dalmatia, on the fly-leaves and inside the covers of the printed book (No. 1599, previously No. 133) ${ }^{1}$ there are four sacred songs and one folk song. These are a) part of the Sticheron in honour of St. Elijah, after the Gloria at Vespers, Mode VI, written inside the front cover; b) three Troparia for the Mother of God as part of a service to Her, without modal indication, on the verso of the last fly-leaf of the book, written upside down and c) part of a threepart song in honour of the Russian Tsar Peter the Great, inside the back cover. As all these songs are of special historical and musical interest, we shall discuss some information which concerns all the songs, and then analyse each one separately.

All these songs were written by the same hand. The texts are written in Church Slavonic, basically the Russian recension, but with noticeable South Russian, Ukrainian and Serbian elements. ${ }^{2}$ The notation is square, the so-called Kievan, ${ }^{3}$ while the $\mathrm{C}$ clefs are written not quite clearly at the beginning of each song, but not with every new line of staff. The notation and text are not in a calligraphic script, but are cursive.

It is difficult to state who wrote these songs and when. Although the book was published in 1615, the later handwritten musical additions, in-

1 Zercalo Bogoslovii, kniga s'stavlena Ieromonahom Kyrilom Traskvilionom blagovoleniem kyr Varlaama Šeptitskogo typogr. pravoslav. obit. Unevskoi, 1615. This is a book by means of which the Uniates wanted to introduce some Catholic theological tenets into the teaching of the Orthodox Church.

${ }^{2}$ Invaluable help in the analyses of the texts was kindly given by Dr Anno Pennington (Oxford).

${ }^{3}$ Interesting data about the origin of this notation gave J. De Castro, Methodus Cantus Ecclesiastici Graeco-Slavici (Roma, 1881). "At the end of the 16th century South Russia began to use, via her metropolis Kiev, the musical notation with staff and notes similar to the Latin ones. This began after a visit of the. Patriarch of Constantinople to the Roman Pope Clement VIII in 1595. Later this European type of notation was changed and received the term Kievan notation." 
cluding the song for Peter the Great (1689-1725) were not added before the first half of the $18^{\text {th }}$ century. The South Russian and Ukrainian elements in the texts, as well as in the melodies of these songs, suggest that the scribe was either a South Russian or a Ukrainian monk who stayed at the monastery of Krka, or possibly, a Dalmatian monk or layman who had spent some time in Russia. It is known in fact that Serbian monasteries and priests in Dalmatia, after the Peace of Karlovac (1699) and that of Požarevac (1718) under the strong pressure of the Venetian authorities and the Catholic Church, often asked for help from Russia. Since the time of the Russian Tsar Peter the Great Russian liturgical books were sent to Dalmatia. The Venetian authorities saw in this a great danger for

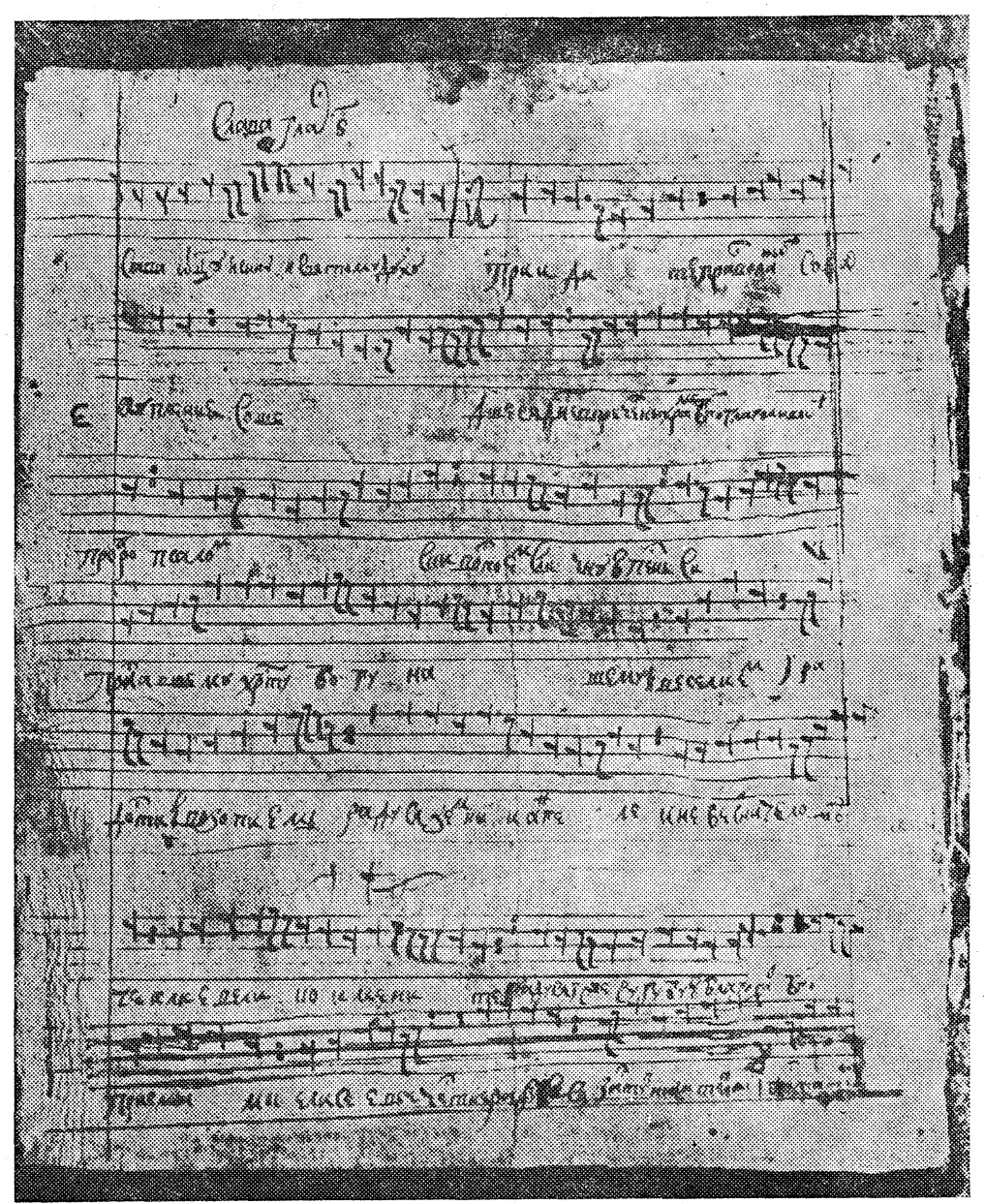

pl. 1 Sticheron in honour of St. Elijah, Modie VI (end is missing). The monastery of Krka, book No. 1599, inside the front cover. 
1. Sticheron in honour of St. Elijah, Mode VI
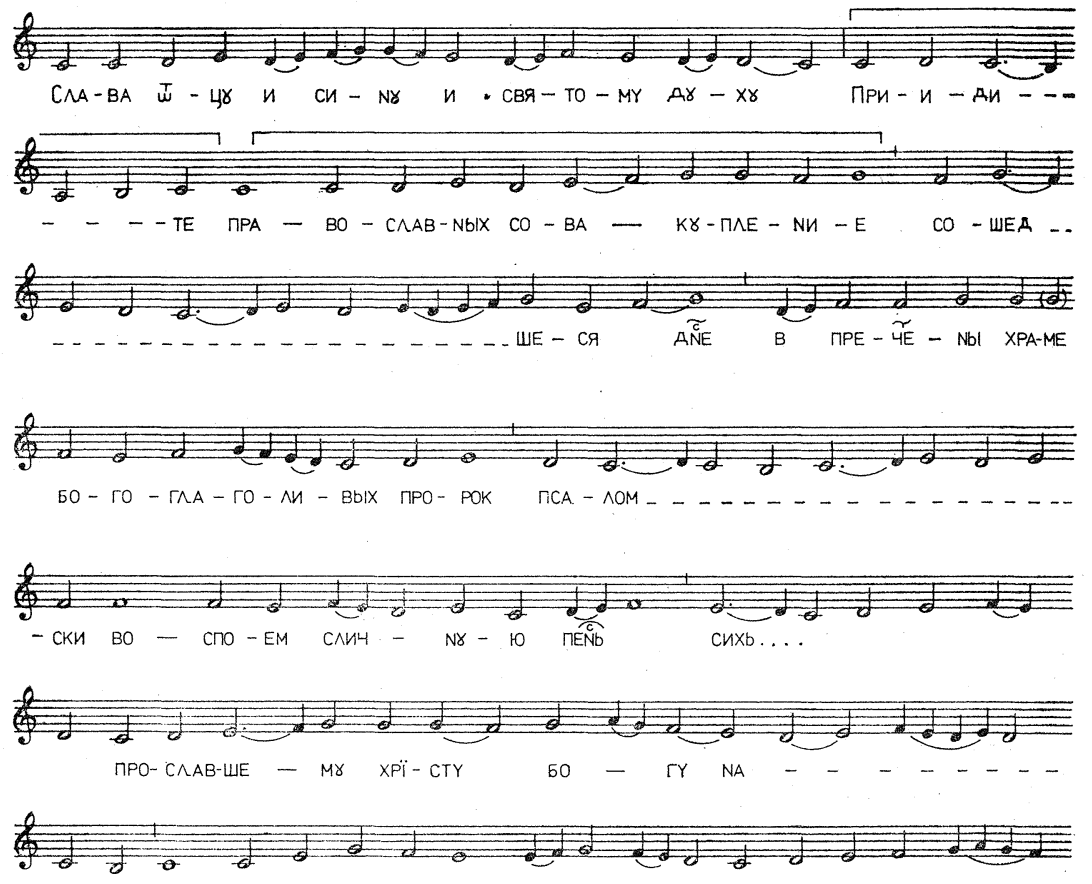

- WE-MY $И$ BE - CE - NH - EM И PA - AO - CTИ- Ю BO - 30- ПИ - EMb
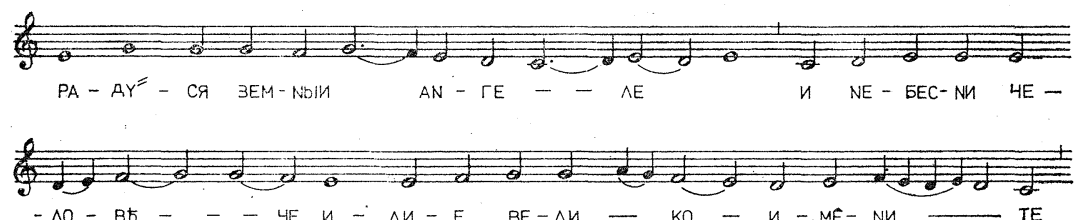

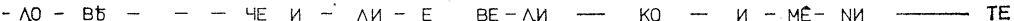

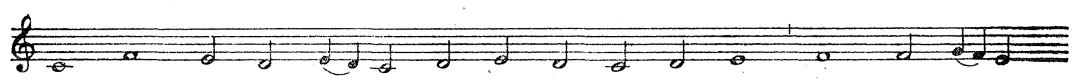
$P A-A Y$

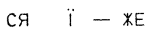
$C Y-\Gamma Y-5 Y-10$
Б八A - ГO - ДАТ
БO $-\Gamma A \ldots$
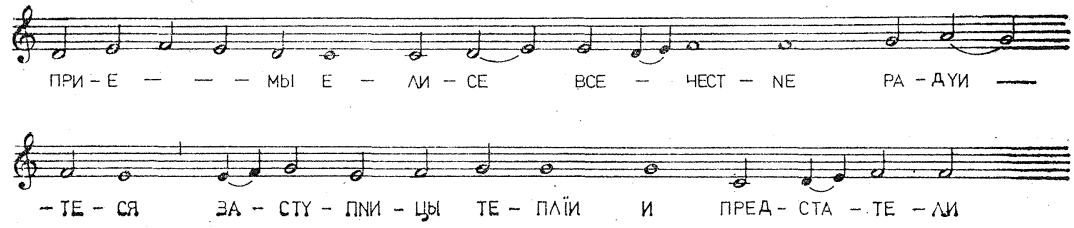

their position in Dalmatia and tried by administrative measures to stop auch connections. ${ }^{4}$ Such political conditions and the danger from the Uniates movement caused the departure of hundreds of people from North Dalmatia, under the leadership of Bishop Simeon Končarević, to South 
Russia in 1757. Some of them returned to Dalmatia at the end of the $18^{\text {th }}$ century. ${ }^{5}$ Of interest is the information that two Russian teachers were sent at the beginning of the $18^{\text {th }}$ century to Croatia to teach the priests. Among other Serbs who studied at the Kievan Theological Academy there was a Dalmatian by name of Evstatije Skerletov. ${ }^{6}$

The first hymn, a Sticheron in honour of St. Elijah PRIIDITE PRAVOSLAVNIH SOVOKUPLENIE is not complete, its final part is missing (pl. 1). The text is in Russian Church Slavonic with elements of the Serbian redaction. Some variant readings exist when compared with the corresponding texts of both the Russian redaction of the $12^{\text {th }}$ century, ${ }^{7}$ and the Serbian redaction of the $15-16^{\text {th }}$ centuries. ${ }^{8}$ The melody is similar to the Sixth Mode of the Russian Oktoechos. Neither the melody nor the form have any similarity to Serbian folk Church singing..$^{9}$ The treatment of the motif is of special interest. It may well be the result of the Western influences (Music example No. 1).

Two melodic phrases at the beginning, in which four motifs can be singled out, are modified and repeated in different forms (augmentation, diminution, inversion etc.) singly or in combinations. Unfortunately we do not have the Russian, South Russian or Ukrainian music of these songs so that we could make a direct comparison. It is noteworthy that the analyses of the Ukrainian Heirmologia of the $18^{\text {th }}$ century show identical realment of motifs..$^{10}$

The question is why did the singer, monk or layman, choose to write down the Sticheron for St. Elijah, which is sung only once during the Church year. It may be that he attended the Patron Saint's Day - Slava - in one of the seven churches in Dalmatia dedicated to St. Elijah. ${ }^{11}$ In connection with this it is worth mentioning that in 1750 , after the pro-

4 D. Kašić, Stanje srpskog naroda i njegove crkve u Dalmaciji u XVIII vijeku, Dalmatinski episkop Simeon Končarević i njegovo doba (Beograd, 1970), p. 33.

${ }^{5}$ D. Lakić, Simeon Končarević episkop dalmatinski i bokokotorski (1751-1757), ibidem, p. 45 .

${ }^{6}$ J. Skerlić, Srpska književnost u 18. veku (Beograd, 1923), pp. 115, 120.

${ }^{7}$ Cf. Russian music manuscripts with kriuki notation, Synodal Library, Moscow (today the Moscow Historical Museum): MS 589 (A. D. 1157), f. 155; MS 572 (12th c.) ff. 153v-154r; MS 279 (12th c.), f. 119r. For the description of these manuscripts see A. V. Gorskij and K. I. Nevostrujev, Opisanije slavjanskih rukopisej Moskovskoj sinodalnoj biblioteki, otdjel III, čast 2 (Moskva, 1917), pp. 314-62, Nos. 517, 518, 519; reprint ed. Monumenta Linguae Slavicae Dialecti Veteris, t. II, no. V (Wiesbaden, 1964).

8. These are texts without notation: Serbian National Library, Belgrade, MS 18 (15th c.), f. 72r; Archives of the Serbian Academy of Sciences and Arts, Belgrade, MS 288 (A.D. 1547), f. 124v; MS 68 (16 ch c.), f. 97r.

9 B. Cvejić, Karlovačko pojanje, IX (Minej za mesec juli), manuscript in the Serbian National Library, Belgrade, pp. 90-2.

${ }^{10} \mathrm{M}$. Antonowycz, The Chant from Ukrainian Heirmologia (Bilthoven, 1974), pp. $39-40$.

${ }_{11}$ These are the churches at Djevrske (1537), Markovac at the Dalmatian Kosovo (1590), Zadar (16th c.), Oton (1702), Ceranj (1712), Zelovo (1865) and Kašic (1868). For this information we are grateful to His Excellency the Bishop of Dalmatia Stefan. 
clamation of one of the many orders of the Republic of Venice against the Serbian population in Dalmatia, a big popular church-gathering took place at the Church of St. Elijah in the Dalmatian Kosovo. "There were present the abbots of the monasteries of Krupa, Krka and Dragović, protopriests, priests, popular leaders and prominent laymen from all the important places of North Dalmatia. ${ }^{12}$

The other musical writing consists of three Troparia to the Mother of God without modal indication (pl. 2): a) ZLATNAA KADILNICE; b)

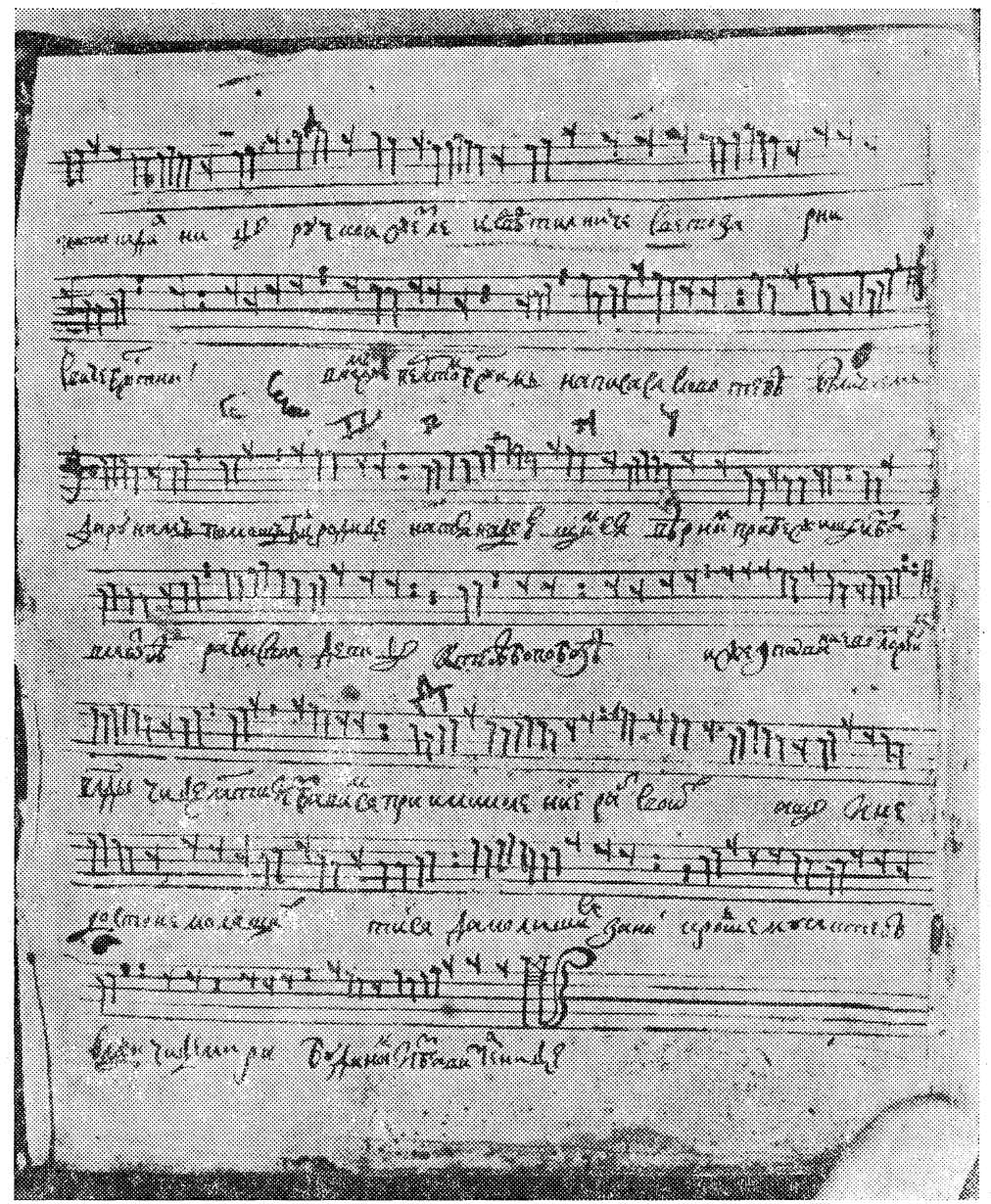

pl. 2 Three troparia from the Moleban to the Mother of God, without modal indication.

The monastery of Krka, book No. 1599, verso of the last fly-leaf of the book (upside down).

12 D. Kašić, ibidem, p. 33. 
DARUI NAM POMOŠC̆; c) VLADIČICE MATI. All three are part of the service MOLEBAN to the Mother of God $^{13}$ and are sung after the ninth Ode of the Canon. In the printed Greek Horologion (Venice, 1853), in the Slavic printed books of the Russian redaction, as well as in the present day Serbian church practice, only the third of the three hymns are found. ${ }^{14}$ The texts of the first two Theotokia were found in manuscripts and printed books of the Serbian redaction from the $16-18^{\text {th }}$ centuries..$^{15}$ At present we do not know whether these texts were eliminated at the time of the reform of the Moscow Patriarch Nikon, ${ }^{16}$ or did not exist in earlier Russian manuscripts. These texts were probably eliminated in Serbia when the Russian practice (the Russian Church Slavonic language and books in this redaction) was adopted in the $18^{\text {th }}$ century. It is also possible that these Troparia were included within the frame of other services. The version which concern's us has some variant readings when compared with the texts of the Serbian redaction. In the third troparion the differences are more explicit when compared with the text of the Russian redaction after the reform of Nikon. Apart from the variant readings we would mention the South Russian and Ukrainian elements in the text. With the evidence adduced we can place the texts in the period before the reform of Nikon. This is quite acceptable when we know that this reform affected the Ukraine only in $1839 .{ }^{17}$

The troparia in our version have no modal indication. Among the manuscripts consulted modal indications are also missing in two manuscripts (Archives of the Serbian Academy of Sciences and Arts, Nos 48, 49), while the manuscript of the Serbian National Library, No. 105, has the indication for Mode VI. In all the other sources mentioned the three troparia are in Mode IV.

The musical material is common to all the three troparia. One characteristic motif is repeated in each troparion several times without changes or with only a rhythmical change. These repetitions follow without any system and appear to be the improvisation of a not very experienced

${ }^{13}$ The main text of the moleban is the Canon in Mode VIII, on Tuesday at the Compline, and is ascribed to the monk Teostirikt (9th c.), cf. Parakletike, the Great Oktoechos.

${ }_{14}$ D. Stefanović, Moleban Bogorodici i njegova dalmatinska muzička varijanía, Dalmatinski episkop Simeon Končarević $i$ njegovo doba (Beograd, 1970), pp. pp. $79-94$.

${ }_{15}$ Serbian National Library, Belgrade, MS 52 (A. D. 1666), f. 163v; MS 105 (17th c.), f. 26v. Archives of the Serbian Academy of Sciences and Arts, Belgrade, MS 48 (17-18th c.), f. $34 \mathrm{v}$; MS 49 (17th c.), ff. 50v-51r; MS 132 (A. D. 1725), f. 134r. Printed books - National Library, Belgrade, I 14, Molitvenik (Mileševo, 1545), f. 238r; I 27, Zbornik za putnike (Mleci, 1597), f. 73r.

${ }_{16}$ The Patriarch Nikon (1605-1681) began with his reforms in the Russian Ortodox Church during the reign of the tsar Alexander Mihailovic in 1652. Cf. M. Florinsky, Russian History and Interpretation, I (New York, 1964), pp. 283-98.

${ }_{17} \mathrm{H}$. Pichura, The Podobny Texts and Chants of the Suprasl Irmologion of 1601, The Journal of Byelorussian Studies, vol. II, No. 2 (London, 1970), p. 199. 
singer. In view of the fact that all three troparia are melodically very similar, the results of the comparative musical analyses of the third troparion can be applied to the two previous ones (Music examples Nos. 2, 3).

2. Two troparia from the Moleban of God

a
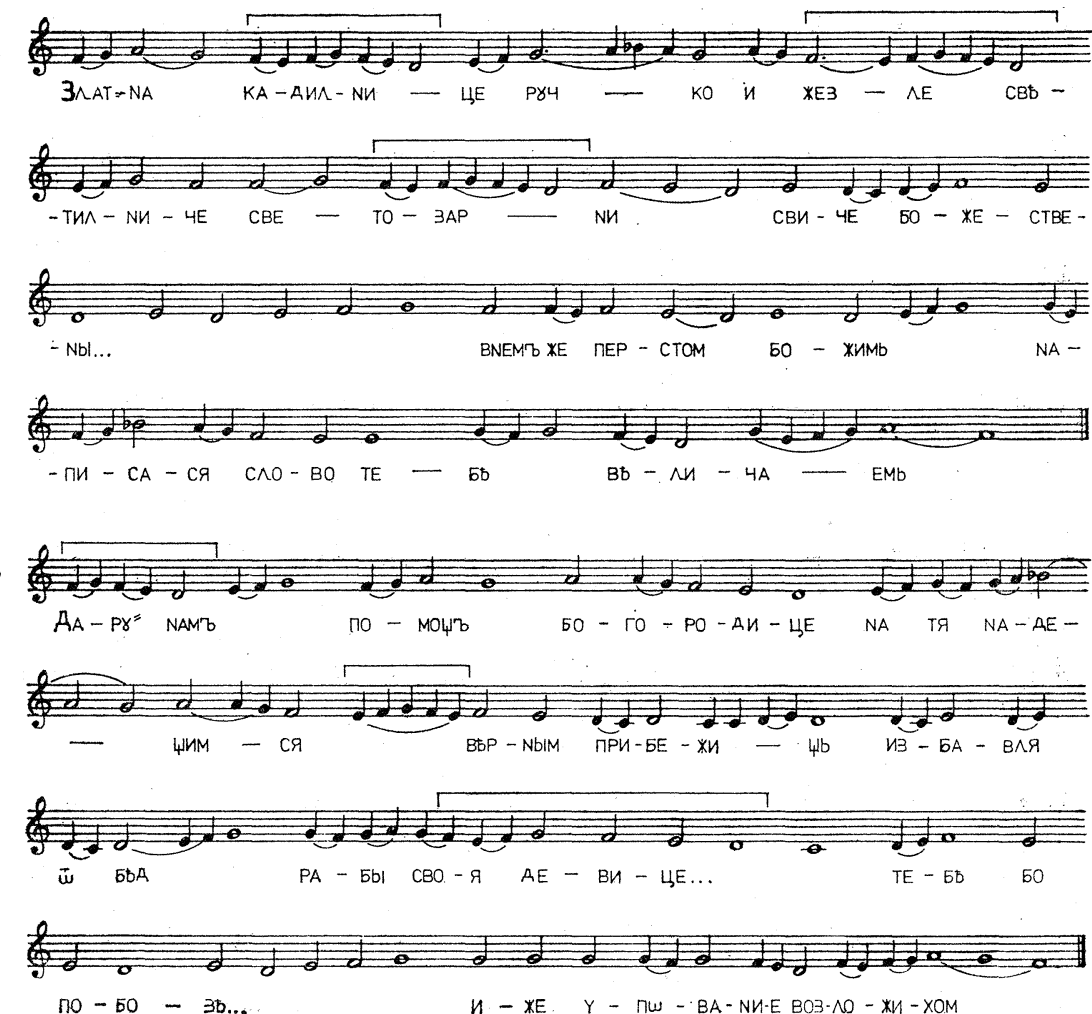

The comparison was based on:

1 the Dalmatian variant of the Serbian church folk singing, from a field recording of D. Stefanović in 1970, the singer was Spiridon-Špiro Šandić, a church singer from šibenik.

2 The Russian znamenny rospev, printed in the book obihod cerkovnago notnago penija (Moscow, 1816), f. 323v.

3 Melodies of the podobny - in a Byelorussian manuscript, the socalled Suprasl Irmologion, Library of the Academy of Sciences of the USSR, Kiev, MS I, 5391 (A. D. 1601), ff. $429 \mathrm{r}-436 \mathrm{v} .{ }^{18}$

${ }^{18}$ Transcriptions and analyses of the texts and melodies of the podobny cf. H. Pichura, ibidem, pp. 192-221. 
3. Troparion from the Moleban to the Mother of God with corresponding music versions

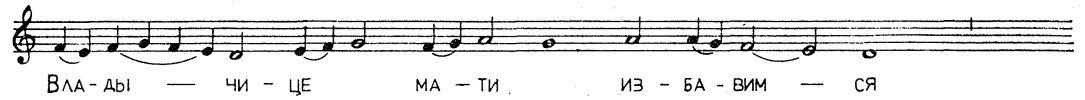

B

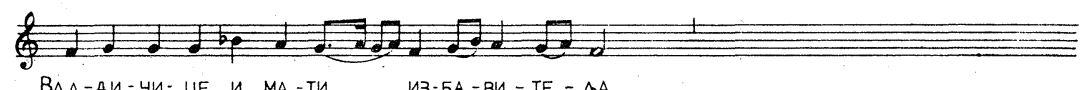

BIA-AИ-4И- LE И MA-TИ ИЗ-5A-BИ-TE - $\triangle A$
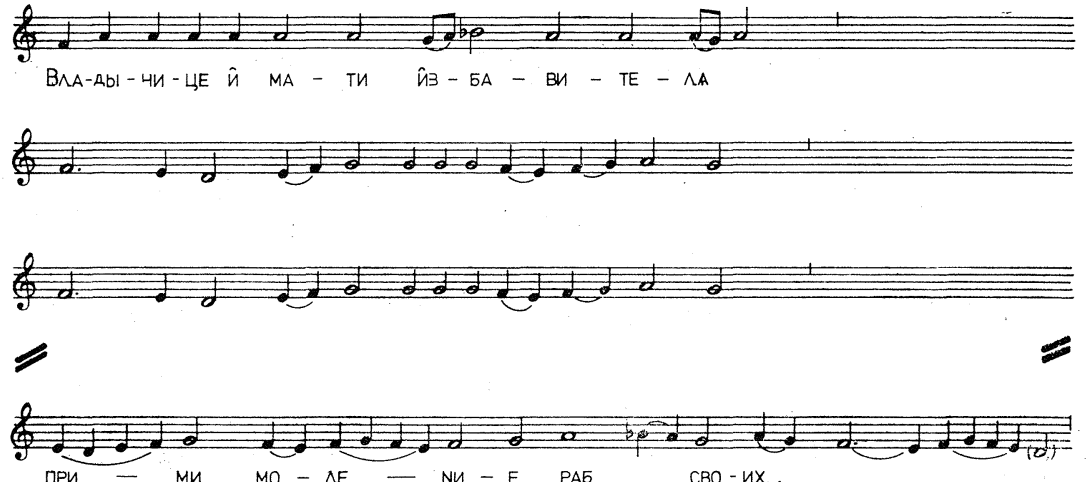

B

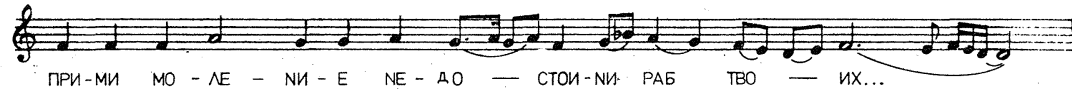

c

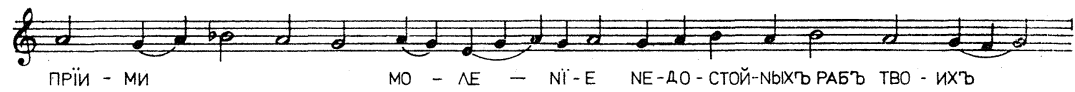

$D$

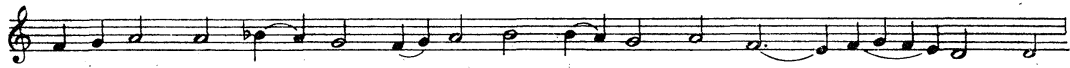

E

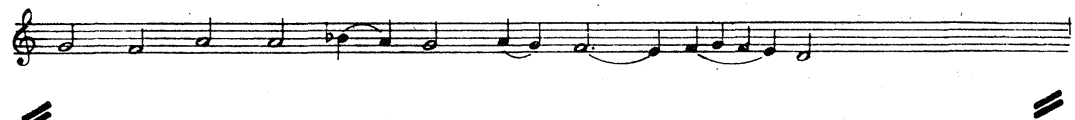

A

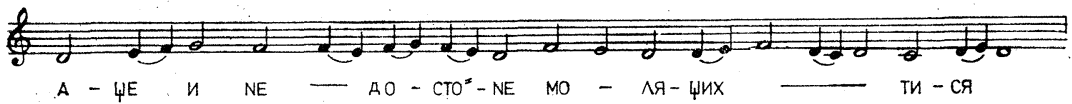

4 Melodies of the podobny in a Ukrainian manuscript with square notation, Archives of the Serbian Academy of Sciences and Arts, Belgrade, MS 64 (A. D. 1674), ff. $254 \mathrm{r}-263 \mathrm{v} \cdot{ }^{19}$

The results of the analyses show that the melodies of these three Troparia were pointed following the Sticheron DOME EFRATOV, the podoben of Mode II, and that they are similar to the Ukrainian variant from the 
A

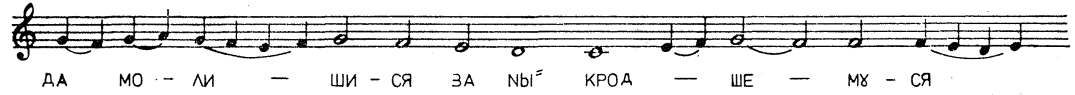

B
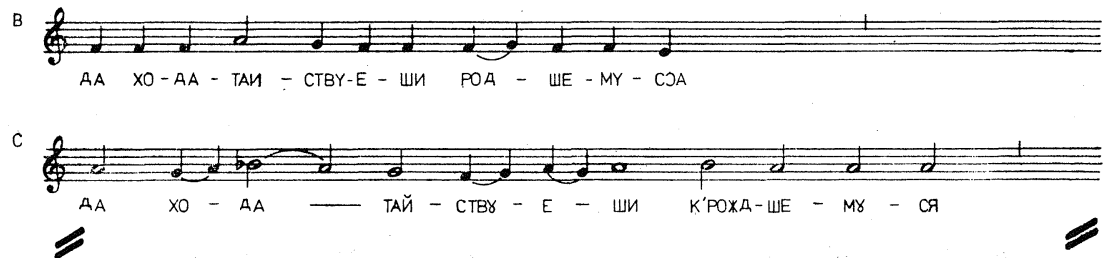

A
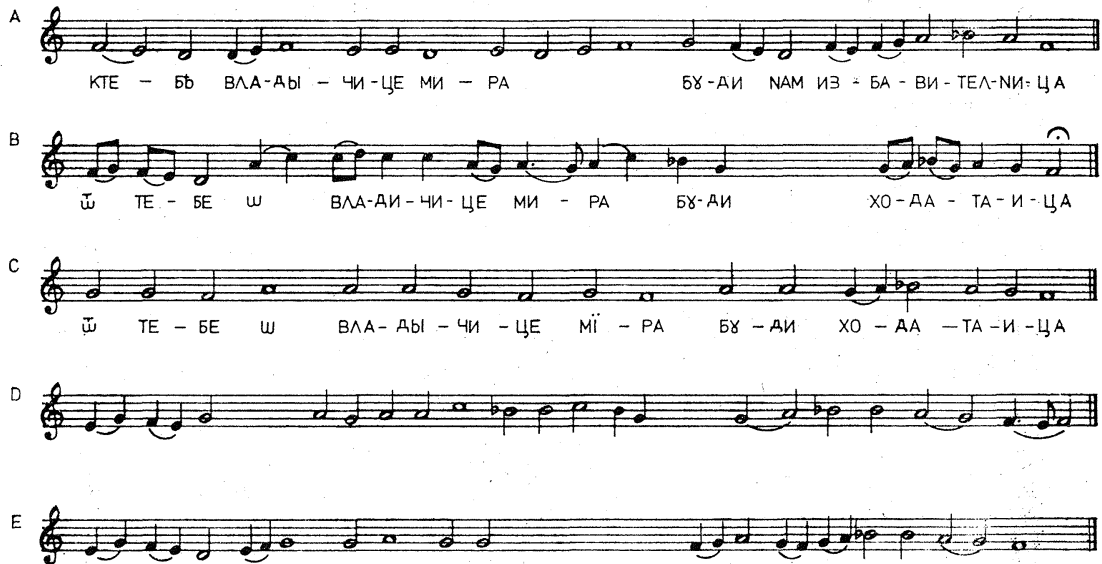

manuscripts mentioned (Music example No. 3). Some similarity exists also with the Dalmatian variant of the Serbian chant, however, the Dalmatian variant, and this is characteristic, concerns the half-cadences and the final cadence. The similatiry of the melodies of Serbian Church singing with Kievan chant (the Ukrainian variant of the Russian znamenny chant) - especially in the cadences - was noticed also during the analyses of the hymns of the Oktoechos and the Stichera in honour of Serbian Saints. ${ }^{20}$

It is not so difficult to explain why our unknown musician chose to write just these not very well known troparia. Even today a custom exists

19 Cf., D. Petrovic, A Liturgical Manuscript with the Russian "hammer-headed" Notation from A. D. 1674, Musica Antiqua III (Bydgoszcz, 1972), pp. 293-319. The Ukrainian origin of this manuscript was confirmed by Prof. Stephen Reynolds of the University of Oregon (USA) in his letter of the 22nd of December 1975.

${ }^{20}$ Cf., Eadem, One Aspect of the Slavonic Oktoechos in Four Chilandari Music Manuscripts, Report of the Eleventh Congress of the International Musicological Society, vol. II (Copenhagen, 1975), pp. 766-74; Hymns in Honour of Serbian Saint in Musical Manuscripts and in Modern Editions, Studies in Eastern Chant IV (in print). 
in the Orthodox churches throughout Dalmatia, in Boka Kotorska and along the Montenegrin Coast, that from 1-14 August (following the Old Calendar) every day a moleban is celebrated to the Mother of God. According to tradition this moleban was introduced as a kind of thanksgiving to the Mother of God that the dangerous infectious disease, plague, stopped at the end of the $18^{\text {th }}$ century..$^{21}$ It is also interesting to find that a similar custom exists in the Ukraine. The Ukrainian Uniates sang the moleban to the Mother of God each day in the month of May.22

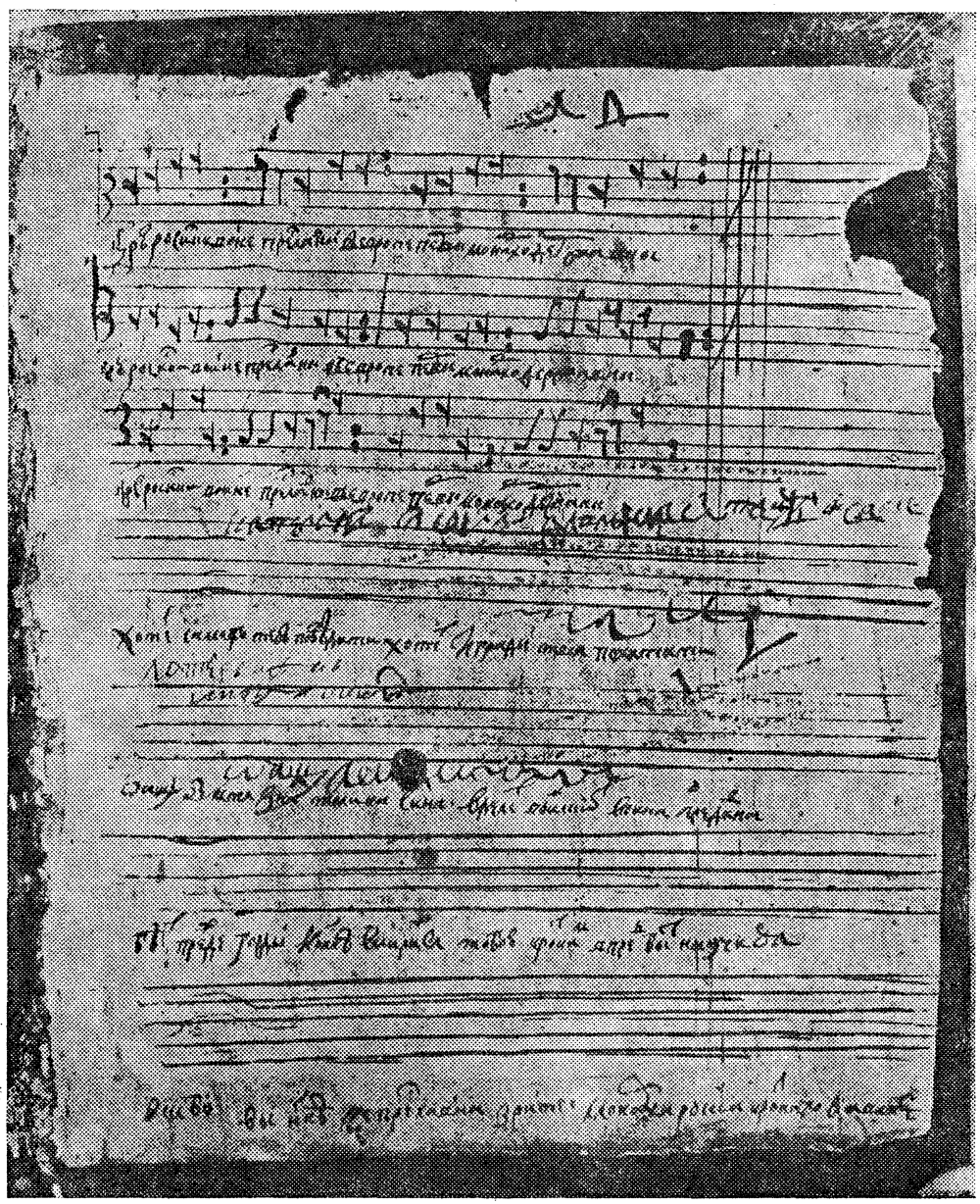

pl. 3 Part of the three-part song to Peter the Great. The monastery of Krka, book No. 1599, inside the back cover.

21 D. Stefanović, ibidem, p. 79.

${ }^{22}$ M. Antonowycz, ibidem, p. 90. 
The last, third song of our copyist is of secular character, written in honour of the Russian tsar Peter the Great and his victory over the Swedish King Charles, in the year 1709. Only two first lines were written with music. Under the musical setting the text of the next eight lines was written (pl. 3).

This is one of the many kanty ${ }^{23}$ which were written in honour of tsar Peter the Great. According to N. F. Findeizen, the praise verses to Peter the Great and his victories were written by teachers of the Slavonic-GreekLatin Academy and their pupils. ${ }^{24}$ As far the contents, these lines have an imprint of church phraseology, but are almost all patriotic. The cult of Peter the Great has crossed the Russian border. Among the Serbs it lasted after his death (1725), during the whole of the $18^{\text {th }}$ century..$^{25}$

Both the text and the melody are incomplete in our book. The text is also not written exactly under the notes. Musically speaking this is only a melodic phrase, which corresponds to one line of the text and should be repeated with the next line. The same kant was published by V. Protopopov from the manuscript in Undolsky's collection, department of manuscripts of the Lenin State Library, No. 898 (first quarter of the $18^{\text {th }}$ century), ff. $38 \mathrm{v}-39 \mathrm{r} .{ }^{26}$ By collating we found out that the third and fourth lines (which with the first two constitute a strophe) are missing in our version, and it is likely that the second musical phrase has also been left out. Only the first two lines are found in other strophes. In both versions the songs are threeparts, but have no melodic similarity. The musical phrase in our version is almost identical with part of the Trisagion melody written under the title "Greckoe Sveti Bože» in the Ukrainian music manuscript (Archives of the Serbian Academy of Sciences and Arts, MS 64 , A. D. 1674 , f. 5 r)..$^{27}$ This melody is also similar to two songs from the Uniate musical anthology. 28 It is probably the older popular melody which has found its way into the liturgical texts and is adapted to different secular songs.

${ }^{23}$ Kanty are popular songs (often of uspiritual" contents), which came to Russia from Poland, through the Ukraine and Byelorussia. Its popularity in Russia dates from the time of Symeon Polocky (1664), cf. A. B. McMillin and C. L. Drage, Kuranty: and Unpublished Russian Song Book of 1733, Oxford Slavonic Papers, III (1970), pp. 1-31. From the Ukrainian literature kanty were also transmitted into the Serbian baroque literature in the 18th century.

${ }^{24}$ N. F. Findeizen, Petrovskie kanti, Izvestija na Akademii nauk SSSR, t. 21, No. $7 / 8$ (1927), pp. 677-87.

${ }^{25}$ Peter the Great was celebrated in Serbian folk literature and in the works of Serbian writers of the $18^{\text {th }}$ century (Z. Orfelin, D. Obradović), cf. B. Mihailovič, Jedna prigodna narodna pjesma o Petru Velikom, Stvaranje, vol. XV, No. 1112 (Cetinje, 1960), pp. 96-98; M. Kostić, Kult Petra Velikog medju Rusima, Srbima i Hrvatima u XVIII veku, Istoriski časopis, VIII (Beograd, 1959), pp. 83-106.

${ }^{26}$ V. Protopopov, Muzika na Poltavskuju pobedu (Moscow, 1973), pp. 37, 206-207.

${ }^{27}$ Cf., Musica Antiqua, III (Bydgoszcz, 1972), p. 316, pl. 2.

${ }^{28}$ Cerkovnoe prostopjenije, noted by Ioann Bokšai (Ungvar, 1905), pp. 4, 161. 
The second part represents an accompaniment in thirds and sixths. The third part, regardless whether we read it in the alto or tenor clefs, does not fit into the harmony of the first two parts. From the harmonic point of view the kanty were very simple and did not pass beyond the common chords and their inversions. We consicler that the most acceptable harmonic chords can be obtained when we understand the melody as being in F-major and than put the third part into a chord with the written intervals. It is a big question whether this procedure is correct and to what extent we have succeeded in avoiding the mistake of a possibly unskilfull copyist (Music example No. 4).

4. Part of the three-part song to Peter the Great

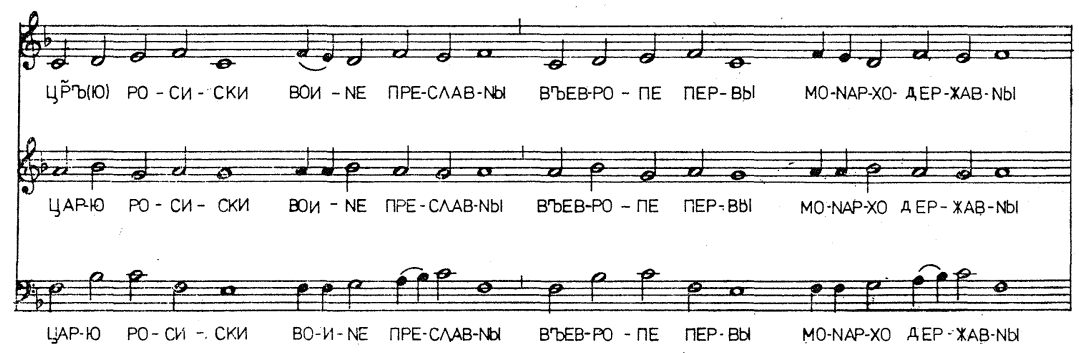

The main and common characteristic of these texts is that all the hymns according to their function, texts or melody testify to the close Ukrainian-Serbian, i. e. Dalmatian, connections in the field of Church music.

The mistakes in the texts and in musical settings reveal an unskilfull copyist, perhaps a Serbian monk or priest who returned from South Russia to Dalmatia.

The connection with the Ukrainian variant of the Russian church singing is found in all the three settings. There are some Ukrainian elements in the Church Slavonic texts of the Russian redaction a $\mathbf{s}$ well as the presence of two Theotokia, possibly from the period before Nikon, and this seems to be a speciality to the Ukrainian tradition where the reforms of Nikon took place some 150 years later. To the unusual daily singing of the Moleban in Dalmatia during the first half of August corresponds also the daily singing of the same Moleban in the Ukraine in the month of May.

Up to the present we have guessed, on the basis of analogous events in the baroque literature, architecture and painting, about the Ukrainian influence on Serbian church music of the $18^{\text {th }}$ century; now we have discovered in these seemingly fragmentary writings of local importance from the monastery of Krka direct evidence about the presence of the Ukrainian church music on our terrain. 


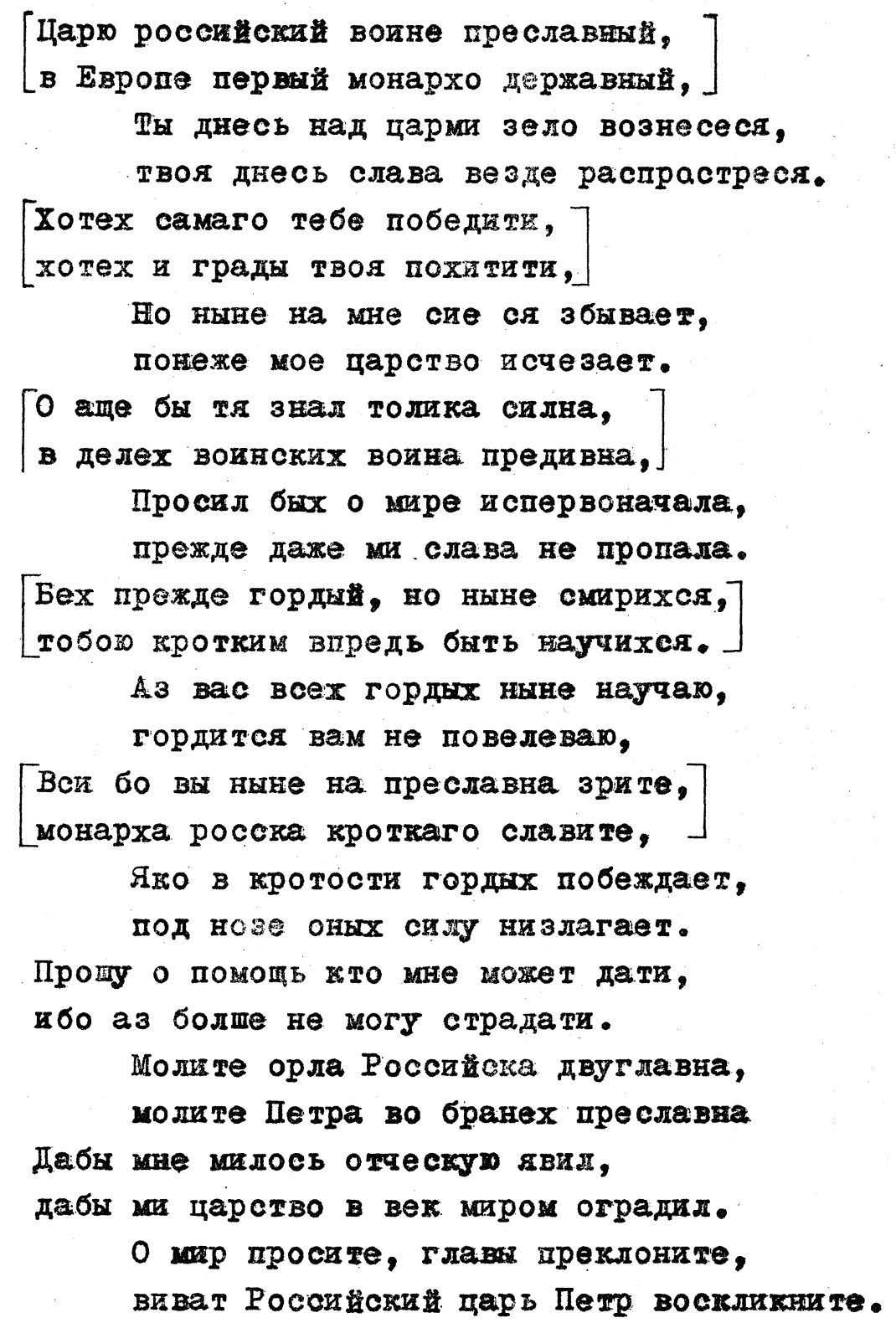

The complete text of the song was published by V. Protopopov, cf. footnote No. 26. Parts of the text which are found in our example are in brackets. 
The results achieved represent an important guide for future research into the great changes to which Serbian church music was exposed in the $18^{\text {th }}$ century.

\section{REMARKS ON THE MUSIC EXAMPLES}

1. In all the music examples the texts are written as they are found in the manuscript and not according to the textus receptus.

2. In music example No. 2 sign $\longrightarrow$ above the music concerns the melodic motif which is repeated.

3. Information about the sources in music example No. 3 .

A - notated text from the monastery of Krka, book No. 1599.

B - the Dalmatian variant of the Serbian Church chant; transcriptions from the tape field recording, sung by Spiridon-Špiro šandić, a church singer from Sibenik; recorded by D. Stefanović in 1970.

C - znamenny rospev, Obihod cerkovnago notnago penija (Moscow, 1816), f. $323 \mathrm{v}$.

D - the podoben of Mode II, Dome Efratov, Suprasl Irmologion, Library of the Academy of Sciences of the USSR, Kiev, MS I, 5391 (A. D. 1601), f. 430r.

$\mathrm{E}$ - podoben of Mode II, Dome Efratov, Archives of the Serbian Academy of Sciences and Arts, Belgrade, MS 64 (A. D. 1674), f. 255r.

\section{POVZETEK}

V knjižnici samostana Krka (Dalmacija), na notranji strani platnic tiskane knjige št. 1599 (stara št. 113), so v ruski kvadratni notaciji zapisane štiri cerkvene pesmi - stihira sv. Iliji in trije Marijini troparji iz Molebna Bogorodici ter ena troglasna posvetna pesem $\mathrm{v}$ čast ruskega carja Petra Velikega.

Osnovna, skupna značilnost teh zapisov je $\mathrm{v}$ tem, da vse pesmi po svoji funkciji, tekstu ali melodiji pričajo o tesnih ukrajinsko-srbskih oziroma dalmatinskih zvezah na področju cerkvene glasbe.

Napake $\mathrm{v}$ besedilih in notnih zapisih kažejo, da gre za neizvedenega zapisovalca, morda srbskega meniha ali duhovnika, ki se je iz južne Rusije vrnil v Dalmacijo.

Zvezo z ukrajinsko varianto ruskega cerkvenega petja najdemo $\mathrm{v}$ vseh petih pesmih. Tu so tudi ukrajinizmi v cerkvenoslovanskih tekstih ruske redakcije. Razen tega, prisotnost dveh Marijinih troparjev, katerih teksti pripadajo jezikovni redakciji iz prednikonovskega obdobja, kar je posebnost ukrajinske tradicije, kjer je Nikonova reforma (1654) bila izpeljana kar 150 let kasneje kot v Rusiji. Neobičajnemu, vsakodnevnemu petju Molebna Bogorodici v Dalmaciji v prvi polovici avgusta ustreza prav tako vsakodnevno petje iste molitve $\mathrm{v}$ Ukrajini $\mathrm{v}$ mesecu maju.

Če smo doslej na podlagi analognih pojavov v baročni književnosti, arhiteizturi in slikarstvu domnevali ukrajinski vpliv na srbsko cerkveno glasbo 18. stoletja, smo $\mathrm{v}$ teh, na pogled fragmentarnih zapisih lokalnega značaja odkrili direktne dokaze o delovanju ukrajinske cerkvene glasbe na našem ozemlju. 